\title{
Morphodynamics of small high-mountain wadis in arid zones (on the examples of the tributaries of the upper Dades River, High Atlas Mountains, Morocco)
}

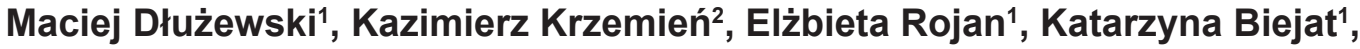 \\ Łukasz Kokosiński ${ }^{1}$ \\ ${ }^{1}$ Department of Geomorphology, Faculty of Geography and Regional Studies, University of Warsaw, Poland, dluzewski@uw.edu.pl \\ ${ }^{2}$ Department of Geomorphology, Institute of Geography and Spatial Management, Jagiellonian University, Cracow, Poland
}

\begin{abstract}
The paper reports on a study of the impact of morphology and lithology of small catchments on episodic river channel development in the southern High Atlas Mountains in Morocco. A detailed analysis focused on three catchments of small wadis featuring different relief and lithology along the upper, middle and lower course of the Dades River. The fieldwork combined with an analysis of topographic and geological maps and of satellite images concluded that the development of the river valley and channel structures was related to the main stages in the development of the landform in this part of the High Atlas. The channel dynamics were found to be typical of arid mountains, which was particularly apparent within a denudational-and-fluvial zone that reached up to 3,000 $\mathrm{m}$ a.s.l. The dominant morphodynamic system of this zone was pluvio-gravitational where episodic heavy rainfall events triggered fast displacement of stone mantle covers down the slopes and into the river channels. An analysis of the deposition zones in the lower channel reaches and on alluvial fans at the confluence of the side valleys and the main valley leads to the conclusion that the main factor, which determines the channel morphology is the impact of debris flows and heavily loaded streams and rivers. The deposited material is then transported outside the mountain zone and deposited within broad river channels. The development of the river channels in the three catchments depends on their order, morphometric property, slope lithology and the amount of material received from the slopes.
\end{abstract}

Key words: river channel morphology, small catchments, upper Dades River, High Atlas, Morocco

\section{Introduction}

Areas with arid and semi-arid climates feature the most important effects on landform development, especially on mountain slopes and in the valleys. These are the locations where the processes of erosion, weathering and sedimentation leave the most visible results following ever more frequent extreme climatological and hydrological events. Such extreme events are the main factor influencing landform transformation in mountain areas (Kotarba 1998). Contemporary geomorphologic processes, both natural and anthropogenic, depend on the natural environment, which in mountains, and especially in high mountains, are known to vary widely even within a small area. The influence of various environmental factors on landforms development has been noted by many researchers (Kühle 1987).

The aim of this study was to determine the influence of morphological and lithological factors on development of episodic river channels in the mountains of the southern High Atlas in Morocco.

\section{Study area}

\section{Location}

Detailed research was made in three catchments that differed in terms of their landforms and lithology and were located in the upper, middle and lower parts of the upper Dades River basin (Fig. 1). Rivers in these catchments are episodic and the only continuous flow, except for the headwater reach, is observed in the Dades River.

\section{Climate}

The upper Dades River basin is located in a arid and semi-arid, mountain climate. The average long-term precipitation in the area ranges from $203 \mathrm{~mm} \cdot \mathrm{year}^{-1}$ at the Msemrir weather station (nearly 2,000 m a.s.1.) to 150 $\mathrm{mm} \cdot \mathrm{year}^{-1}$ at the Boumalne station (at the lowest point of the catchment 1,526 $\mathrm{m}$ a.s.1.). A semi-arid climate, especially in mountains, is characterised by wide fluctuations in annual precipitation. Between AD 1962 and AD 2008, 


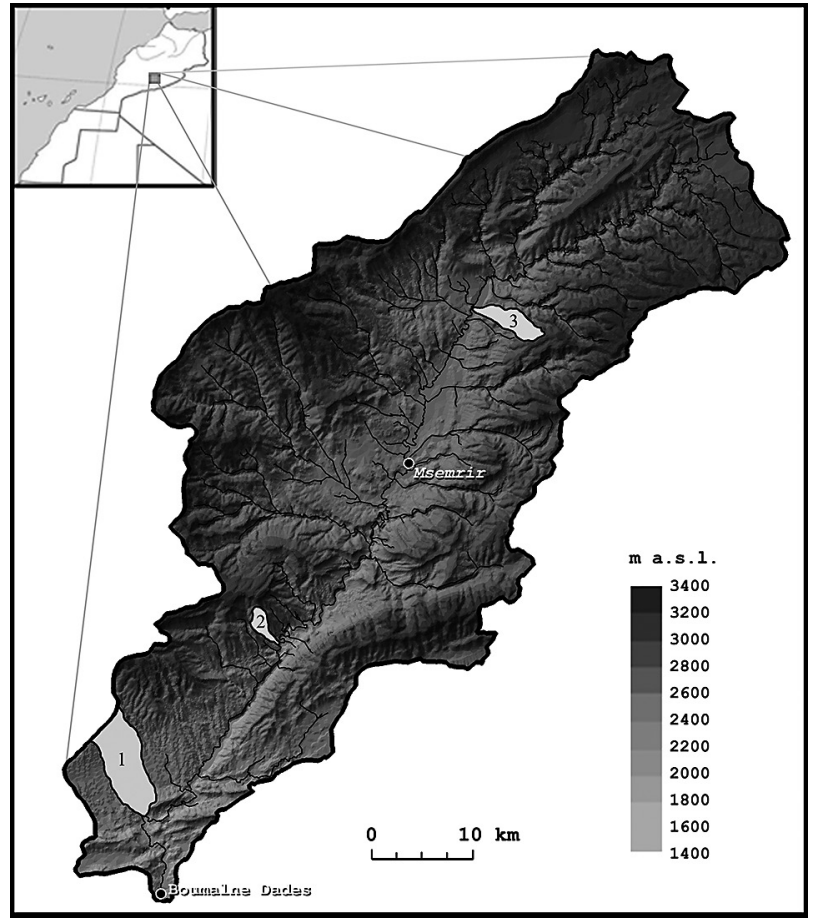

Fig. 1. Study area of the upper Dades basin with the three catchments analyzed in detail (based on DTM Model, Google Earth)

the maximum ranges were from 50 to $392 \mathrm{~mm} \cdot \mathrm{year}^{-1}$ at Msemrir and from 30, to nearly $300 \mathrm{~mm} \cdot \mathrm{year}^{-1}$ at Boumalne (de Jong et al. 2008). In the highest sections of the High Atlas the maximum precipitation can reach $900 \mathrm{~mm}$ and the total daily maximum can reach nearly $100 \mathrm{~mm}$ (Schulz et al. 2008). Precipitation peaks between September and December and between March and May, while during other seasons of the year, especially in the summer, there is typically no precipitation.

For two to four months each year, the highest parts of the river catchment are covered with up to several metres of snow (Schultz, de Jong 2004). However, due to the low overall air humidity and strong solar radiation up to $40 \%$ of the water contained in the snow is lost through sublimation. In the water balance of the upper Dades River ba$\sin 49 \%$ is accounted for by evapotranspiration and only $28 \%$ by subsurface drainage, just $3 \%$ of surface outflow, and $20 \%$ by various forms of retention within the catchment (de Jong et al. 2005).

\section{Hydrology}

The volume of outflow varies widely both along the main river and seasonally. In its upper sections it is normally a few cubic metres per second, but this increases, to more than $10 \mathrm{~m}^{3} \cdot \mathrm{s}^{-1}$ during extreme events. At the Ait Moutad hydrometric post (upstream from Boumalne) the long-term average outflow is $33.3 \mathrm{~m}^{3} \cdot \mathrm{s}^{-1}$ (de Jong et al. 2008). The outflow in the Dades River channel, except its headwater reach, is even greater because it is supplied by high-yield underground karst sources during dry periods.

\section{Geological structure}

The folded range of the Atlas Mts. is the youngest structural unit on the African continent. It belongs to the Euro-Asian belt of Alpine folded units despite having been formed partly during the Caledonian and Variscan orogenies. Its oldest folded structures were rearranged by tectonic processes at the time of the Alpine orogeny and built into its structures (Brzezińska-Wójcik, Tsermegas 2006). Much of the High Atlas' relief developed during the two phases when the Atlas system was formed, i.e. the late Eocene - Oligocene and Upper Pliocene - Lower Quaternary (Frizon de Lamotte et al. 2000).

The Upper Dades River basin is fully contained within the structural unit of the Atlas Mountains and consists of uplifted ranges, whose cores of various ages were folded, dislocated and subject to upthrust in the early Tertiary and have since undergone numerous deformation and erosional cycles (Laouina 2006). The existing drainage system of the Dades River basin probably started to develop during the Pliocene or Pleistocene epochs (Stokes et al. 2008).

The lowest of the selected catchments (Z1) is mostly composed $(86 \%)$ of continental conglomerates of Neogenic age. The conglomerates consist of very well rounded stones more than $10 \mathrm{~cm}$ diameter, arranged in layers of between tens of centimetres and several metres in thickness. A certain amount of middle Liassic limestone and marl interbedding is also found at $1950 \mathrm{~m}$ a.s.l. at the top of the catchments (13\% of the catchment area). The limestone layer, measuring less than one metre in thickness, is much more resistant to physical weathering than the marl causing the slopes to develop an uneven step-like profile. At the lowest point of the river catchment is a small area (less than 1\%) composed of massive lithified limestone and dolomite of lower Liassic age that is highly resistant to abrasion.

The middle catchment (Z2) is mostly (93\%) composed of highly folded black limestone. The limestone comes in layers several tens of centimetres thick often with marl interbedding. In the lower part of this catchment there are interbedded limestones and marls of Middle Liassic age (7\%). The alternating rock layers of different resistance invite the shape of step-like slope profiles in a similar manner to that found in the upper catchment (Z1).

The uppermost catchment (Z3) mostly consists (ca. $71 \%$ ) of oolitic limestones and marls of Middle Dogger age. Again, just as in the other two catchments, this geology results in an uneven slope profile, as a more rapid weathering of marls leads to the opening of gaps below the limestone layers and, as a consequence, to intensified rock-falling on very steep cliffs or to rock creep on less inclined slopes. The middle section of this catchment $(16 \%)$ is built of marls of Middle Dogger age with numerous fossils. Their lower resistance to erosion results in a more mature valley relief characterised by much longer side slopes and a wider bottom. The lowermost part of the catchment $(13 \%)$ is built of oolitic and oncolytic limestones and, in places, of Middle Dogger sandstones and 
marls. Differences between their resistance and the direction and incline of their layers lead to a differentiation in the slope incline and to gravitational mass movements.

\section{Vegetation cover}

The vegetation of the upper Dades River basin is very modest due to the climatic conditions and, in the lower part of the catchment, also due to an intensive human pressure. It includes typical xerophyte shrubs, including Sclerocephalus arabicus Boiss and Epherda alata Decne, growing on average to a height of 20-30 cm but never more than $50 \mathrm{~cm}$. The prevailing average diameter of each specimen is $30-50 \mathrm{~cm}$. Their number was assessed using the Braun-Blanquet scale (Wysocki, Sikorski 2009). In the lowest parts of the Dades river basin the cover-abundance falls within group 1, where each species covers less than $5 \%$ of the territory. Specifically this is mostly group $1 \mathrm{r}$ (1-2 specimens) and sometimes $1+(2-5$ specimens $)$ with the overall average density of $1-1.5$ shrubs per $\mathrm{m}^{2}$. In the upper part of the Dades river basin the cover-abundance belongs to group 2 where each species covers between $5 \%$ and $25 \%$ of the area and the number of specimens is large. There are places where the cover-abundance drops to group 1 level. The overall average specimen density is 2.5-3 shrubs per $1 \mathrm{~m}^{2}$. The proximity between individual specimens is used in the Braun-Blanquet scale to describe the suitability of the conditions for a given species (Wysocki, Sikorski 2009). While in the lower parts of the Dades basin it is mostly rated as 1 (individual specimens grow in isolation) with sporadic areas rated at 2 (specimens in groups), the upper parts show a pattern that is the exact reverse. Also the size and density of the shrub specimens grows with altitude and distance from the main valley. This is explained by the increased precipitation, which offsets various other conditions typical of a high-mountain climate and must be seen as the crucial factor in the contemporary vegetation cover in semi-arid areas. The difference in the density and size of the vegetation cover between higher and lower parts of the catchment is also driven by strong human pressure from settlements along the main river and primarily involving herb picking and sourcing firewood. Herding is strong across the entire river catchment.

\section{Research methods}

Three catchments were selected for detailed study. Their analysis was used to identify the influence of landforms and lithology on the development of intermittent river channels (Figs. 1, 2). The fieldwork included the identification of channel ordering according to A. Strahler's (1952) classification system, their length, gradient, sinuosity, channel network density and slope inclination. The catchments were also analysed for their geology, especially the lithology and structure. Topographic and geological maps at scales of 1:50,000 and 1:100,000 were used, as well as satellite images. The fieldwork to identify the channel relief was performed in June and October 2012. It included the measurement of channel geometry and the size of the bedload in specific reaches. The relationship between the intensity of intermittent discharges and bedload material was analysed. The slopes were assessed for their potential to supply material into the channels looking at their lithology, structure, length and angle. The slopes were also analysed for the amount of their waste-mantle, the density and species composition of the vegetation cover, including its count and proximity according to Braun-Blanquet's scale. The role of erosion and deposition was also determined in the development of the channel morphometry at each order level. The stage of channels development at corresponding order levels was compared between the three catchments. Finally, lithological and landforms features were identified that had a key influence on the morphometry of intermittent river channels in arid mountain river catchments.

\section{Results}

\section{Catchments morphometrics}

The selected catchments differ in size (Figs. 1, 2) ranging from $3 \mathrm{~km}^{2}$ (Z2) to just over $7 \mathrm{~km}^{2}$ (Z3) and to nearly $23 \mathrm{~km}^{2}$ (Z1) (Fig. 2, Table 1). They are also located at different altitudes from the lowest point at 1,600 $\mathrm{m}$ a.s.l. to the highest at 2,900 $\mathrm{m}$ a.s.l. Within each catchment the relative altitude range from $525 \mathrm{~m}$ (Z1) to $812 \mathrm{~m}$ (Z3) (Table 1). Two of the catchments (Z1 and Z2) are exposed towards the SE and one (Z3) towards the NW (Fig. 1).

Slope angles in the catchments range from several to $90^{\circ}$, but areas with an inclination greater than $30^{\circ}$ are relatively very limited $(\mathrm{Z} 1-2 \%, \mathrm{Z} 2-7 \%, \mathrm{Z3}-4 \%)$, which is not typical of a mountainous area. Each of the catchments has a different dominant slope angle. The entire lowest catchment $(\mathrm{Z} 1)$ is relatively gently sloping with $86.5 \%$ of its terrain falling within $0-15^{\circ}$, within which there is a small prevalence of slopes angled $5-10^{\circ}$. The middle catchment (Z2) is clearly different, and one half of it is sloping at between $20^{\circ}$ and $30^{\circ}$ while almost $32 \%$ falls within $15-20^{\circ}$ bringing the proportion of $15-30^{\circ}$ slopes to nearly $82 \%$. Also, close to $5 \%$ of the total area is angled at $30-40^{\circ}$ and gentler slopes represent about $4 \%$, including $5-10^{\circ}$ at $0.4 \%$ and $0-5^{\circ}$ at less than $4 \%$. (The latter category is the lowest of all the catchments, as it represents $29 \%$ of the area in Z1 and $13 \%$ in Z3). In the highest catchment (Z3) the largest (33\%) single slope category is $10-15^{\circ}$ followed by $15-20^{\circ}(26 \%)$ and $0-5,5-10$ and $20-30^{\circ}$ (ca. $12 \%$ each).

The main river channels also differ in gradient between the catchments. The most gradual main channel gradient is found in the lowest catchment $(Z 1-56 \%$ o), it becomes twice as steep in the highest catchment $(Z 3-110 \%)$ and twice as steep again in the middle one ( $Z 2-228 \%$ ). 
Table 1. Catchment morphometrics

\begin{tabular}{lccc}
\hline \multicolumn{1}{c}{ Morphometrics } & Catchment 1 & Catchment 2 & Catchment 3 \\
\hline Area $\left(\mathrm{km}^{2}\right)$ & 22.73 & 2.95 & 7.39 \\
\hline Length of main channel $(\mathrm{km})$ & 9.34 & 3.20 & 7.36 \\
\hline Source altitude of main wadis (m a.s.l.) & 2,125 & 2,455 & 2,887 \\
\hline Lowest point of main wadis (m a.s.l.) & 1,600 & 1,725 & 2,075 \\
\hline Height difference along main channel (m) & 525 & 730 & 812 \\
\hline Average of main channel gradient (\%) & 56 & 228 & 110 \\
\hline Sinuosity of main channel & 1.18 & 1.14 & 2.23 \\
\hline Tributaries per 1 km of main channel & 2.05 & 0.86 & 2.03 \\
\hline Length of all channels $(\mathrm{km})$ & 72.07 & 8.50 & 3.29 \\
\hline Density of channel network $\left(\mathrm{km} \mathrm{km}^{-2}\right)$ & 3.17 & 2.88 & \\
\hline
\end{tabular}

The catchments share a similar channel network density at ca. $3 \mathrm{~km} \mathrm{~km}^{-2}$, ranging from $2.88 \mathrm{~km} \mathrm{~km}^{-2}$ in the middle catchment and $3.17 \mathrm{~km} \mathrm{~km}^{-2}$ in the lowest (Table 1). Looking at the number of tributaries per kilometre of main wadis, the middle catchment (Z2) stands out with the lowest value of 0.86 , while the other two are almost identical at 2.03 and 2.05 (Fig. 2).

There is not much variation between the sinuosity indices of the main channels, which range from 1.14 in the middle catchment to 1.23 in the highest one (Table 1).

\section{Development of the river channels}

\section{Catchment Z1}

Lithology is the main factor responsible for the variation between the order of the channels in the lowest catchment. Order I channels are cutting into limestones and marls and can be well developed just $100 \mathrm{~m}$ from their headwaters, especially in the upper sections of the catchment. The gradient of order I channels and valley slopes is strictly linked to the geology. In the headwater area, layers of limestone and marl are sloping (at ca. $10^{\circ}$ ) in the same direction as river flow. Above 2,000 m a.s.l. precipitation is much heavier than in the lower parts of the

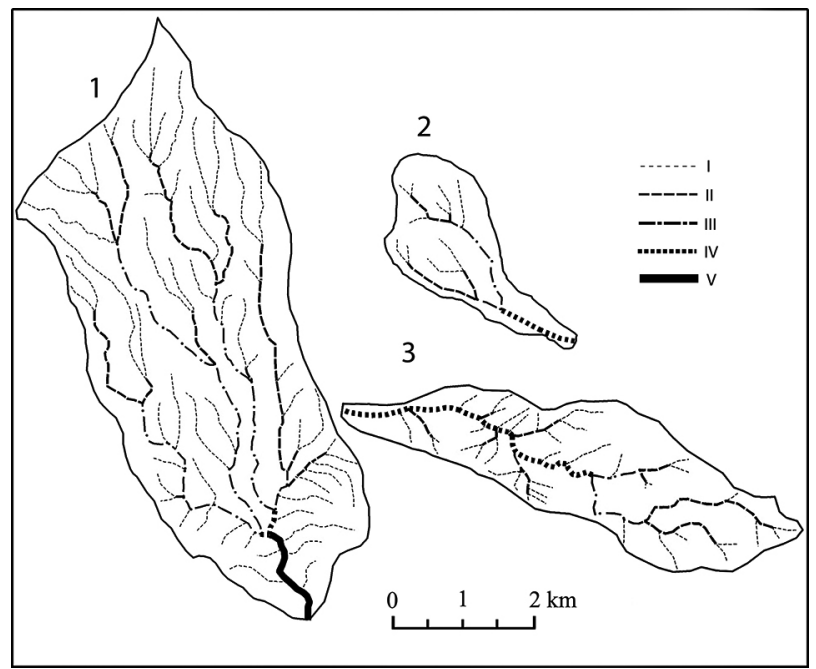

Fig. 2. Intermittent river channels of various orders (I-V) in the studied catchments (based on: topographical map: Boumalne, 1:100,000, 1968; Tineghir, 1:100,000, 1968) catchment and this provides a sufficient amount of water for intensive linear erosion despite quite dense vegetation cover (Fig. 3A). The slope material is displaced and deposited in the valley bottom. There intermittent water discharges, normally very low, are just sufficient to carve salient channels through the rocky debris, but not to fully eroded the bottom of the valley. Indeed, order I channels cut no more than $0.5 \mathrm{~m}$ into their bedload, ranging from sandy-gravel to small pebbles $(5-7 \mathrm{~cm})$, and very poorly sorted.

Limestone and marl channels of order II are far better developed due to intensive erosion during downpours (Fig. 3B). Their valleys cut more than ten metres into the bedrock and their sides fall at angles of ca. $15-25^{\circ}$. Again, the channels slope in the same direction as the limestone and marl layers. The higher energy of water in these channels helps sweep more of the material arriving from the sides away down the valley, leaving the valley bottoms mostly clean and devoid of deposition forms. There are numerous steps of $0.5-0.7 \mathrm{~m}$ in height or series of steps of maximum height $1.5 \mathrm{~m}$, depending on the thickness of the rock laminae (Fig. 3B). The few deposition reaches contain sharp-edged material with a dominant fraction of $5-7 \mathrm{~cm}(\max .35 \mathrm{~cm})$.

Channels of order II cutting into conglomerates are highly varied in character. In the upper part of the catchment, where the channels gradient is $180 \%$, they are often devoid of deposited material, which attests to a high erosion energy. The latter is even greater in some channels that narrow down to less than one metre at the bottom with vertical rocky banks several metres high on both sides. Channels cutting into conglomerates differ from limestone channels in featuring numerous evorsion potholes $0.5-0.7 \mathrm{~m}$ deep and steps that are higher (up to 2 $\mathrm{m})$, but more spread-out. The lower sections of the channels flatten out significantly (to $50-70 \%$ ), widen (to more than 10 metres) and change their nature from erosion to deposition-driven, often with a very clear boundary between them. Slopes in conglomerate valleys have greater angles (up to $40^{\circ}$ ), which helps supply large volumes of material into the channels. At this stage, the much more gradual and wider channels run far calmer waters when compared with upstream reaches. The material deposited here is dominated by material of $15-25 \mathrm{~cm}$ that are often 


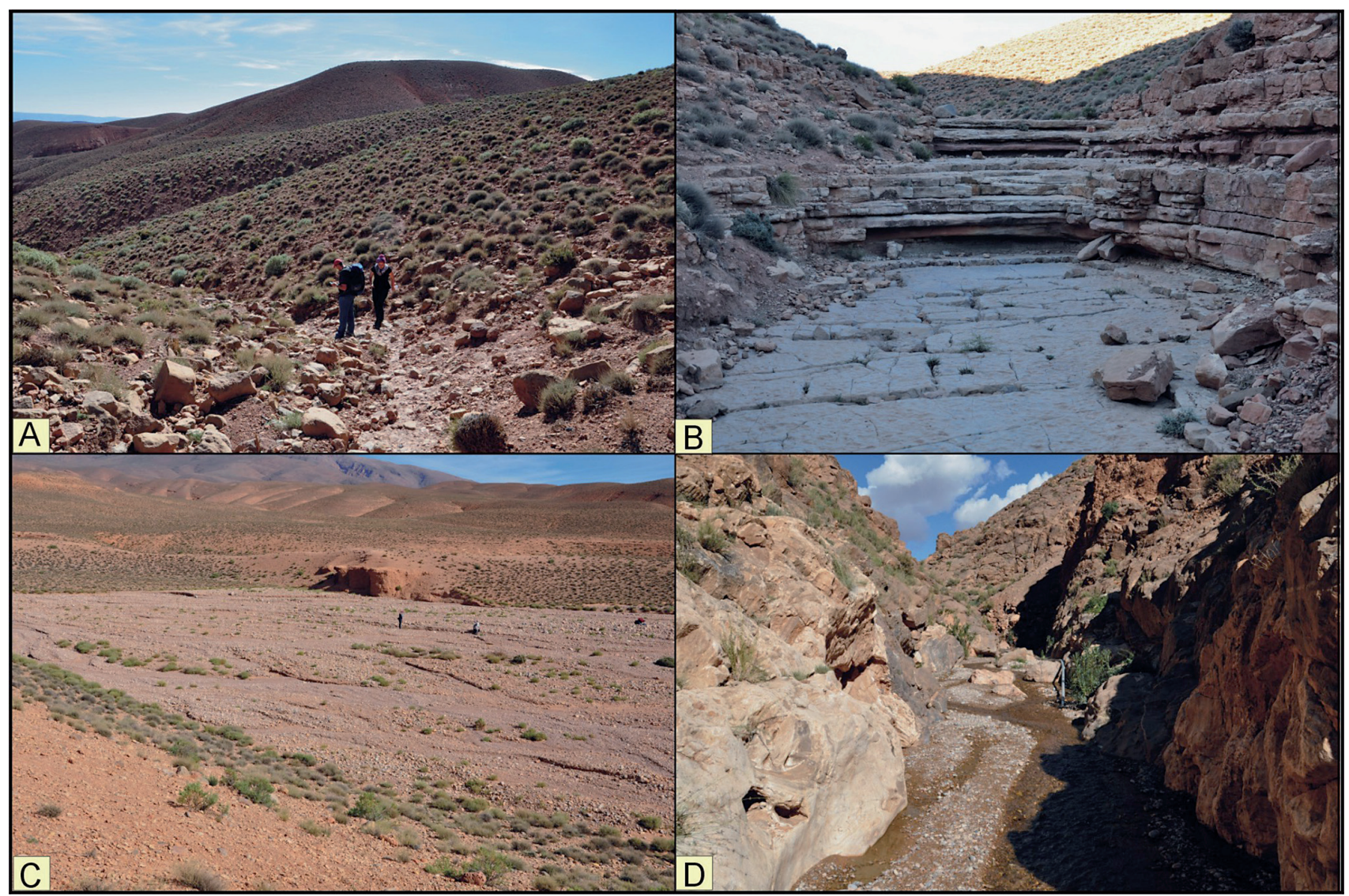

Fig. 3. Examples of different orders of channel in catchment Z1

$\mathrm{A}$ - the upper part of order I channel cutting into slopes with somewhat dense vegetation; B - order II bedrock channel bottom in limestones and marls with a system of steps; C - order III channel cutting in conglomerates with a multi-current system and median bars; D - narrow order; V channel cutting into massive limestones and dolomites

very well rounded. The degree of roundness, however, is not made by abrasion when transported by the rivers, but of their original rounding received during the Neogene before they formed conglomerates in large alluvial fans.

The order III channels and short reaches of order IV channels have typical multi-channel systems of braided rivers. They are much broader than order II channels (up to $70 \mathrm{~m}$ ) and very gentle (up to $50 \%$ ). Conglomerate channels, as has already been mentioned, clearly dominate in the lowest section of the catchment (Fig. 4C). The geology and the minimal slope of the area causes the watersheds separating adjacent catchments to form expansive and nearly flat elevated surfaces. Despite only having sparse vegetation, the surfaces are little eroded and supply virtually no material into the channels. Valley slopes tend to be short (100-200 m), gentle (5-10 $)$ and do not supply much material into the channels. Any intermittent supply of material into the order III channels comes from very limited surfaces of steeper slopes (up to $30^{\circ}$ ). Consequently, it may be concluded that the bedload transported by order III rivers originates on the slopes of order I and II channel reaches. It is transported intermittently depending on the duration and intensity of the precipitation. When that is light or short, but still sufficient to ensure discharge in the channel, only the smallest and the lowest-located channels are shaped. Their dominant bedload size is 5-7 $\mathrm{cm}$. When the precipitation is heavy or prolonged, pro- ducing bankfull flows, the entire channel is shaped; starting with material with a size of 10-15 cm (max. $57 \mathrm{~cm})$ found in channels bars (Fig. 3C). These events, however, seem to occur no more than once in several years.

The single order $\mathrm{V}$ channel in the lowest catchment provides a very good example of the influence of geology on channel development. It cuts into massive limestones and dolomites (Fig. 3D) and despite the high erosional energy of the water during precipitation, it has not developed into a wide-bottomed channel, like order III and IV channels, but has remained narrow $(2-6 \mathrm{~m})$ and is mostly filled with large bed load material. It features several rocky steps, including one that is more than six metres high. Its valley sides are quite steep and become nearly vertical on the concave sides of the bends. Erosion clearly dominates over deposition despite the very gentle gradient (up to 50\% except steps) and large volume of material supplied from the sides and upstream reaches.

The channel is building a vast $(200 \mathrm{~m}$ long and $70 \mathrm{~m}$ wide) alluvial fan at the confluence with the Dades River. Several main branches and more than ten minor branches cut through the fan and are filled with pebbles that are mostly well-rounded and measure 5-7 cm in diameter. Following downpours, the fan begins to function and expand, as material is deposited in farm fields at its peripheries. In extreme cases the forward section of the fan may push the Dades River towards its other bank. 


\section{Catchment Z2}

The channels of the middle catchment (Z2) cut into alternating layers of limestones and marls. This highly uniform lithology across the catchment means that the contemporary development of the channels is determined primarily by the amount of episodic discharge while secondary roles are played by the catchment's relatively large average slope and the gradient of its channels (which is the greatest of all the three catchments).

Order I channels are quite steep (200\%o-300\%o), which increases the erosional strength of the relatively small volume of water available in channels of this order. The valleys cut deep (down to 15-20 m) and feature steep sides $\left(\max .40^{\circ}\right)$, which accelerate linear erosion and increase the supply of slope material into the valley bottom. All these factors, however, fail to produce sufficient water energy to sweep the valley bottom clean of the deposited debris. The channels tend to be narrow $(0.6-1.5 \mathrm{~m})$, but cut deep (down to $1.5 \mathrm{~m}$ ) into the layer of rock debris, the size of which reaches up to $50 \mathrm{~cm}$ (Fig. 4A).

Order II channels are characterised by relatively high water flow intensities as a result of the catchment's low potential for water retention in just a thin layer (up to 20 $\mathrm{cm}$ ) of large material and among sparse vegetation. Very steep channel gradient (ca. 150\%o-200\%) and their low width (1-6 m) also play an important role here. The channels cut deep into the slope-originated debris (down to $2.5 \mathrm{~m}$ ) filling the valley bottoms (Fig. 4B). Episodic flows during precipitation are greater than in order I channels and this enhances the transporting power to a point where it can be sufficient to start even coarse-grained material $(23-30 \mathrm{~cm})$. The channels feature reaches with both deposition and erosion predominant. In tighter spots, where the flow is faster, erosion dominates and the bottom is lined with coarse-grained material (20-30 cm or more). Where the channel becomes wider (up to $6 \mathrm{~m}$ ) the flow slows down and deposition increases, involving a mix of material ranging from the dominant $7-10 \mathrm{~cm}$ size to $50 \mathrm{~cm}$. There are sporadic rocky steps, which slope downwards (at ca. $10^{\circ}$ ) in line with the slope of the limestone and marl layers. This large variation in the shape of order II channels points to their important role in the transport of material downstream.

The functioning of order III channels differs considerably from that of order II channels. Because of their potentially higher flows, only marginally greater widths and similar volumes of material from the side slopes, order III channels experience greater rates of downcutting. This means that in reaches at a gradient ca. $180 \%$ o the $7-10$ $\mathrm{cm}$ material is swept downstream during almost every flow. The majority of the bead load material has the size of $15-25 \mathrm{~cm}$, but the maximum size $30 \mathrm{~cm}$ is also present. These material are started during bankfull flows. Where reaches are significantly steeper $(250 \%$ ou to $350 \%$ in places), patches of exposed bedrock appear devoid of any alluvial material (Fig. 4C). These channels feature numerous rocky steps or series of steps on limestone outcrops up to $2.5 \mathrm{~m}$ in height. Despite the large volume of bed- load transported by the episodic flows no evorsion hollow are found directly beneath these steps. This would suggest a high resistance of the limestone rock to evorsion, which is bound to be impeded by the fact that the limestone as well as marl layers are mostly sloping down the valleys. These order III channel reaches are clearly of an erosion-transport nature. Order III channels are also very stable in terms of their course viewed in plan.

The only order IV channel in this catchment begins at the upper part with a steep section (ca. 180\%o) and steep side slopes (mostly $30^{\circ}-40^{\circ}$, but often much more than that). During episodic flows, coarse material $(10-30 \mathrm{~cm})$ is transported along the channel. There are narrow stretches (3-7 m wide) several dozen metres long and with rocky steps 1-1.5 m high where erosion becomes even more dominant over deposition and the channel is swept to bare rock. Downstream, the channel widens (to 14-21 m) and channel gradient decreases (ca. 100\%o), which reduces considerably the potential flow intensity. As the role of deposition increases, so the channel braiding tendency grows with a number of parallel channels running over an alluvial bottom and separated by bars (Fig. 4D). During flows, the river fills these channels and incises their bottoms with the bedload it carries. As water velocity drops, the material is deposited, starting from the largest to the finest fraction $(5-7 \mathrm{~cm})$. Only rare bankfull flow cause redevelopment of whole channels as they start to move both the fine fraction $(5-7 \mathrm{~cm})$ in the channel bottom and the coarsest material $(20-30 \mathrm{~cm}, \max .60 \mathrm{~cm})$ in the channel bars.

A large alluvial fan more than $160 \mathrm{~m}$ wide at the front has developed at the confluence with the Dades River. The fan has a dual structure; its northern part, accounting for nearly a half of the whole, is built of clearly coarser material $(50-70 \mathrm{~cm})$ and rises 1-2 $\mathrm{m}$ above the other part and is no longer active. The lower section consists of finer material $(10-30 \mathrm{~cm})$, which is affected during each flow. A dozen small channels change their course during each flow, distributing the water over the surface of the fan. The dual structure of the fan, visible in the different granularities, suggests hydrological events of much higher erosional and transporting energy in the past.

\section{Catchment Z3}

Geology is the main factor differentiating the river channel morphometry and it also has a significant influence on their sinuosity and gradient. The two parameters combined with the amount of episodic water in the channel define the flow intensity. The amount of water is linked primarily with the order of the channel and, to a much lesser extent, with the catchment potential water retention due to the very low density of vegetation in all but the highest parts of the catchment.

While order I channels are characterised by quite high gradient (ca. 150\%o-180\%o) they barely cut into the debris. This is explained by low flow intensities caused by low water volumes and by structurally determined wide (up to $50 \mathrm{~m}$ ) valley bottoms where the channels are also 


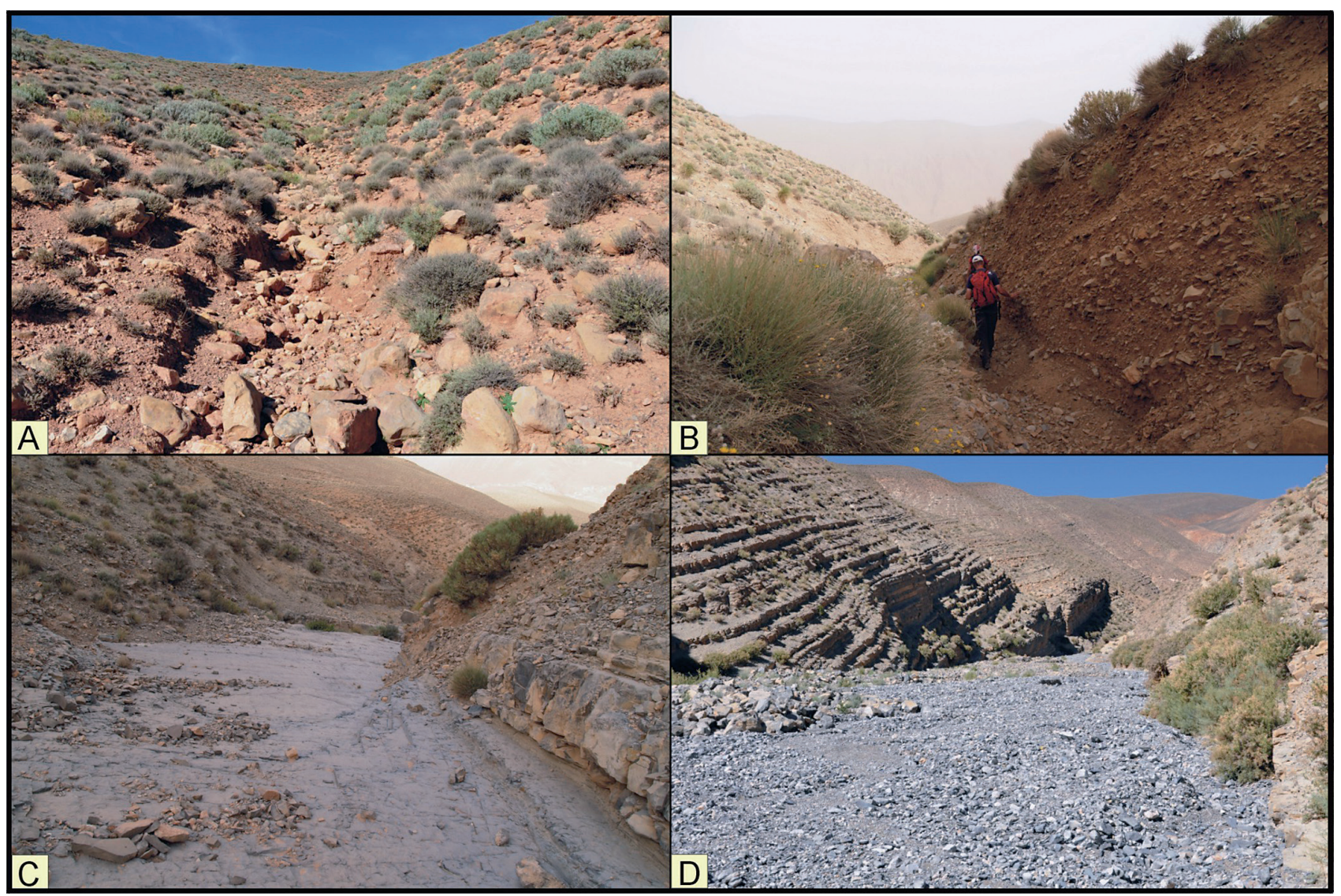

Fig. 4. Examples of different orders of channel in catchment Z2

A - order I channel cutting in a substrate composed of slope material (limestone and marl); B - a narrow order II channel cutting deep into the slope-originated rock debris; $\mathrm{C}$ - order III channel with limestone bedrock bottom and a slope concurrent with the slope of the rock layers; D - deposition/transport order IV channel with subchannels and channels bars

considered wide (2-3 m) when compared to other headwater channels. The dominant fraction is $10-12 \mathrm{~cm}$, but even the maximum fraction is not much larger at $15 \mathrm{~cm}$, which would confirm that the flow intensity remains low even during the heaviest precipitation. The lower reaches of order I channels are far better developed, carved into the debris (down to $0.5-1 \mathrm{~m}$ ) filling the valley bottom (Fig. 5A), but remain narrow $(30-70 \mathrm{~cm}$, max. $1.5 \mathrm{~m})$ due to the low volumes of water available. This water flow is also insufficiently powerful to move the largest size boulders $(\mathrm{ca} .1 \mathrm{~m})$ that contribute to low steps $(0.3-0.5$ $\mathrm{m}$ ) along the channel, behind which develop small evorsion kettles (up to $1 \mathrm{~m}$ in diameter). In these long reaches the channels follow stepped longitudinal profiles. Steps of similar height also develop on the sparse outcrops of limestone layers. Large boulders found in the channels tend to deflect the water flow causing extensive lateral erosion, which is not observed in order I channels of other catchments.

Moving down from order I to order II channels there is a considerable difference in shape. The channels grow broader (2-3 m, max. $7 \mathrm{~m}$ ) and their gradient begins to vary greatly $(50-150 \%)$ leading to smaller incision depths. The channel bottoms are still filled with coarsegrained slope debris $(20-30 \mathrm{~cm})$ (Fig. 5B) and only beneath the sporadic channel-wide rocky outcrops does deposition increase and do the channels grow even broader.
The fine-grained $(3-5 \mathrm{~cm})$ sharp-edged material deposited there confirms the low transporting power of the episodic flows. The valley sides slope at $20-25^{\circ}$ supply relatively little material due to the relatively strong vegetation cover in this part of the catchment basin. The channels become more stable in their pattern in plan view; the role of lateral erosion diminishes considerably and is confined to reaches with outcrops of rock layers that change the direction of the current. There are spots with marginal bars built of coarser material $(7-10 \mathrm{~cm}$, max. $30 \mathrm{~cm})$, which start to be formed during the highest flows.

Order III channels vary widely in shape, including width $(2-8 \mathrm{~m})$, channels gradient $\left(50 \%{ }_{0}-200 \%\right.$ ) and even sinuosity $(1.12-1.4)$. This is due to the transverse or diagonal pattern layers of rock vis-à-vis the course of the channels. Series of steps often develop on these outcrops each up to $2.5 \mathrm{~m}$ in height. A lack of evorsion hollow directly beneath the steps attests to the high abrasion resistance of the rocks. The steep slopes $\left(30-40^{\circ}\right)$ of the deeply-cut valleys supply large volumes of debris into the channels. In many places steep slopes give way to cliffs ranging from ca. $70^{\circ}$ to vertical and the intense thermal weathering conditions (wide daily fluctuations in air temperature) intensify rock fall and rock creep processes (Fig. $5 \mathrm{C})$. Dislodged pieces of rock are sharp edged often quite large (up to several meters in size) and their size is linked to the thickness of the rock layer (up to $1.5 \mathrm{~m}$ ). Rocks dis- 


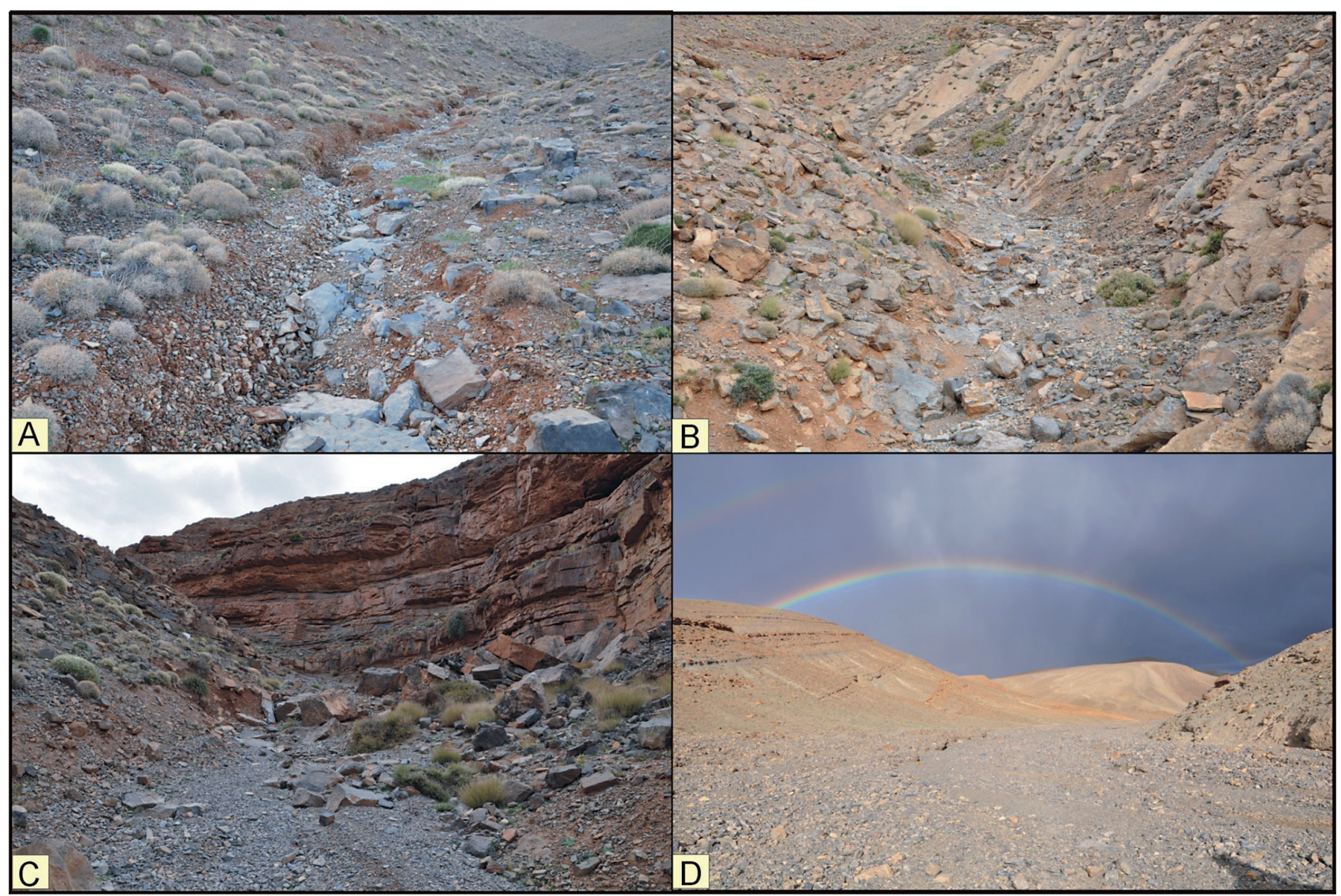

Fig. 5. Examples of different orders of channel in catchment Z3

A - lower sections of a order I channel cutting into slope-originated deposits filling the valley bottom; B - a order II channel with coarse-grained (20-30 $\mathrm{cm}$ ) material from the slopes; $\mathrm{C}$ - a order III channel with boulders supplied by rock falls; D - broad and gentle order IV channel with deposition predominant

placed from vertical cliffs fall directly into the channels, while on slopes angled at $50^{\circ}-80^{\circ}$ they slide down during downpours or over the snow cover that can be quite frequent at these altitudes (above 2,300 $\mathrm{m}$ a.s.1.). Talus cones or even large isolated boulders can impede or dam the river flow forcing the current to find its way around and causing local lateral erosion that undercuts rock cliffs and widens the channels. This is where the greatest degree of modification occurs to the channel course.

Downstream, small gradient $\left(50 \%{ }_{0}-100 \%\right.$ ) characterizes the order III channels, influences the deposition and transport as the dominant processes. The latter depends on the channel width and the existence of side bars. At times of low flow, only small channels carry water transporting material of 5-7 cm size. At bankfull flows, the water dislodges and carries material deposited on bars $(12-15 \mathrm{~cm}$, $\max .40 \mathrm{~cm}$ ). This indicates wide fluctuations of water flow in these channels. In some reaches erosion prevails while in others deposition is the dominant process.

In the order IV channel deposition clearly dominates despite the potentially largest discharge (Fig. 5D). This is explained by the gradient drop (to $30 \%{ }^{-}-50 \%$ ) and an increase in the width (to $20-27 \mathrm{~m}$, with $10 \mathrm{~m}$ in only a few places). This is a typically braided channel with many branches and bars. The side slopes are several hundred metres in length, often steep $\left(30-40^{\circ}\right)$, sometimes featuring a dual-angle profile with the top section at $50-80^{\circ}$ or even vertical, which provides the right conditions for a high volume of supply into the channel. This is not impeded by the very sparse and weak vegetation. During low flows, when the water runs through the smaller channels, only the fine $(3-5 \mathrm{~cm})$ fraction is transported, while bankfull flows dislodge the material deposited in the channel bars $(10-12 \mathrm{~cm}, \max .40 \mathrm{~cm})$. The fact that material of this size is dislodged in a channel so wide suggests a high transporting power during bankfull flows. These events completely change the course of the current and the location of the channel bars. An alluvial fan built at the confluence with the Dades River has a frontal width of $80 \mathrm{~m}$. The confluence reach is very gentle (ca. 35\%o) and the river has less power to supply material to the fan than in the middle catchment (Z2) and its surface is more stable.

\section{Channel development and dynamics}

Channel dynamics can be studied by looking at their overall shape, individual channel relief features and the material transported during flows. River channels record effects of extreme events when the landform undergoes rapid transformation. For these reasons the authors paid particular attention to marks left by these events in the channel morphometry. Fluvial landforms and the material transported during flows offer a good basis for understanding the landform change of the study area. 
The three catchments studied differ quite substantially in terms of channel development, which depends on their order, morphometrics, geology and the amount of debris received from the slopes. Certain similarities can be found, including a key role played by the supply of large amount of slope-borne debris in the development of order I, II and often also order III channels. These volumes are large where the slope angle exceeds $20-25^{\circ}$, i.e. along most of the valleys in catchments $\mathrm{Z} 2$ and $\mathrm{Z} 3$ and in the upper part of catchment Z1. Intensive erosion of the valley slopes owes much to intensive physical weathering and sparse vegetation, which are typical of high mountains in arid zones.

The slope debris deposited in the valleys cut in marls and limestones has helped order I channels achieve good levels of development and deep incision, despite their short distance from headwater areas. Water flow in order I channels, however, lacks sufficient power to cut through the debris to the bedrock, even if the channels are quite steep (Fig. 6a). In the channels incised into conglomerates, slope sediment supply is significantly smaller and, despite low discharge, all bedload material is mobilised by the water flow. Channels of this order are developed mostly due to downcutting (Fig. 6b). It takes an increase in the amount of water and steepness in order II for the rivers to start fully sweeping the valley debris (Fig. 6a). In this order the deposition balance is negative in channels cut in marls, limestones as well as in conglomerates (Fig. 6a, b) and the downcutting prevails. The most varied morphometry occurs in order III channels. This is due to their lithological variation and differences in valley maturity. Channels cut in limestone and marls tend to be deep with steep valley slopes. Despite the large volumes of debris supplied into these channels, downcutting prevails over deposition. Lateral erosion also begins to play a significant role (Fig. 6a). Where order III channels cut into conglomerates, they are typically braided channels with deposition and redeposition dominating (Fig 6b). They are gentler, much wider and have several currents within the channel. Their valley slopes are shorter and much less steep, which reduces the importance of slope debris in the channel. In all of the catchments studied, order IV channels were typically braided regardless of the geology, valley maturity or the supply of slope debris. The volume of water flowing was the single most important channel-making driver. At low flows only individual sub-channels were remodelled, but at bankfull flow the course of entire channels and the location of channel bars were affected. Transportation and redeposition of bedload prevails in these channels and downcutting plays an insignificant role. However, lateral erosion is important, leading to change in the channels pattern and channel bars (Figs. 6a, b). Conglomerates which are less resistant to mechanical abrasion facilitate development of relatively wider channels comparing with limestones or marls. The only order V channel, in catchment Z1, has different morphometrics than order IV channels and provides a typical example of impact of geology on a river channel. Large a)

\begin{tabular}{|c|c|c|c|c|}
\hline \multirow{2}{*}{$\begin{array}{l}\text { Channel } \\
\text { order }\end{array}$} & \multirow{2}{*}{$\begin{array}{l}\text { Main direction of channel } \\
\text { development }\end{array}$} & \multicolumn{3}{|c|}{$\begin{array}{c}\text { Intensity of main } \\
\text { morphodynamic processes }\end{array}$} \\
\hline & & erosion & transport & deposition \\
\hline I & & ++ & + & +++ \\
\hline II & & +++ & + & + \\
\hline III & & +++ & ++ & + \\
\hline IV & & ++ & +++ & +++ \\
\hline
\end{tabular}

b)

\begin{tabular}{|c|c|c|c|c|}
\hline \multirow{2}{*}{$\begin{array}{c}\text { Channel } \\
\text { order }\end{array}$} & \multirow{2}{*}{$\begin{array}{l}\text { Main direction of channel } \\
\text { development }\end{array}$} & \multicolumn{3}{|c|}{$\begin{array}{c}\text { Intensity of main } \\
\text { morphodynamic processes }\end{array}$} \\
\hline & & erosion & transport & deposition \\
\hline I & & +++ & + & + \\
\hline II & & +++ & ++ & + \\
\hline III & & + & ++ & +++ \\
\hline IV & & + & +++ & +++ \\
\hline
\end{tabular}

Fig. 6. Main direction of channel development in: a) marls and limestones, b) conglomerates

1 - channel erosion, 2 - channel deposition, 3 - lateral erosion

alluvial fans have developed at the confluence of all the channels with the Dades River. There is a strict relationship between the morphodynamics of the alluvial fans and the development of their channels.

\section{Discussion}

Development of river channels in high mountains of arid and semi-arid areas is very diversified irrespectively of their location. This is why classification of the channels and identification of factors responsible for their development are difficult tasks (Cooke et al. 1993). Previous research shows that long periods with little or no channel activity interrupted by intense rainfall-runoff events that lead to short-lived but high-energy flash floods are the most important factors influencing channel development in this area (Leopold et al. 1964). This pertains to channels of all orders. However, study performed in catchments of the Upper Dades basin shows that river channels can vary significantly between the orders, therefore factors responsible for their development are more complex than the single flash flood events. Usually, water energy is treated as the main factor responsible for morpholog- 
ical diversification of the river channels of different orders. This factor depends on river discharge linked to the channel order and flow velocity which, in turn, depends on channel gradients. Deposition and erosion in consecutive channel orders depend on energy of water and slope sediment supply (Powell et al. 2007). Most frequently, in channels of the I, II and sometimes even III order erosion dominates despite low discharges, because high channel gradient increases water energy which is able to erode slope material delivered to the channel (Tooth, Nanson 2004). However, increased delivery of the slope material, especially in the upper reaches of catchments, can modify this pattern. Such a situation is not necessarily linked to limited hillslope vegetation (Thornes 1980), but can stem from increased weathering of bedrock, which in turn depends on lithology and relatively severe climatic conditions in the upper parts of the catchments. Significant production of loose weathered material together with rapid runoff generation facilitate abundant coarse-grained sediment supply.

The study performed in the Upper Dades basin decidedly shows that lithology is one of the major factors controlling diversification of episodic river channels in high mountains in this climatic zone. Despite lower gradient and low energy of water in channels of I and II order, conglomerate bedrock favours erosion over deposition. Massive conglomerates are much more resistant to physical weathering in comparison to bedded and highly jointed marls and limestones. The channels of I and II order developed in conglomerates are more incised into bedrock and have narrower floors due to dominating downcutting. On the other hand, channels developed in marls or limestones develop under significant influence of the bedrock internal structure. In channels of III and IV order developed in conglomerates water energy is also low which results in intensive deposition. This is related to increased width of the channels and often lower gradient in comparison with channels developed in marls and limestones. Increased width of the channels results from low resistance to mechanical abrasion of conglomerates under action of coarse-grained material. Very narrow channels of IV and even $\mathrm{V}$ order occurring in the studied area are related to increased resistance to mechanical abrasion of the bedrock.

Lithology plays a very important role in development of mountain river channels not only in drylands. However, relationship between slopes sediment supply and bedrock resistance to mechanical abrasion is highly pronounced in arid areas. Sparse or nonexistent vegetation in river basins such as the Upper Dades does not influence diversification of sediment supply, therefore is does not play a role in diversifying channel development. High amount of sediment supply and highly variable flow regimes are thought to be main factors responsible for almost permanent nonequilibrium state of dryland rivers (Graf 1988). However, results of this study show that certain bedrock types, because of their resistance to physical weathering, are responsible for very slow morphological change of channels of I and II order. Such channels can be seen as ones in a state of relative equilibrium despite variable flow regime.

\section{Conclusions}

The structure and dynamics of various ordering channels in the upper Dades River basin, on the southern slopes of the High Atlas Mountains, is very varied. The structures of the valleys and channels are linked to major stages in the development of the region's landforms. The channel dynamics are linked with characteristic climatic conditions of arid-mountains zone. The impact of the dry conditions on this specific section of the mountains is best seen within the denudational or denudational/fluvial vertical zone, which peaks at 3,000 m a.s.l. Here, fluvial processes dominate in the valley bottoms while erosion prevails on the slopes. The leading pluviogravitational morphodynamic system in this zone involves episodic downpours and floods which trigger violent displacement of the waste-mantle on the slopes and in the valley bottoms. These processes play very important roles in the landforms development. Fast deposition in the lower part of valleys and on the alluvial fans suggests a strong role of debris flow and torrential flow on channels development on this area.

The research reported in this study focused specially on the denudational/fluvial zone and the patterns mentioned above have been confirmed. Decomposed rock occurred in these types of areas is on the beginning transported into the side valley floor and then deposited on the alluvial fans at the confluence of the side valleys and the main valley. The material is then swept downstream and deposited in broad channels beyond the mountains. The research has demonstrated that only a certain proportion of debris can be transported from the highest mountain zones outside the mountains.

\section{Acknowledgments}

The study is supported by the National Science Centre, project No. 2011/01/B/ST10/07295.

\section{References}

Brzezińska-Wójcik T., Tsermegas I., 2006. Geologiczne uwarunkowania rozwoju rzeźby Atlasu Wysokiego na przykładzie wąwozu Ziz. In: M. Dłużewski, I. Tsermegas (eds.), Geograficzne i geologiczne uwarunkowania rozwoju rzeźby Maroka. Materiały Warsztatów Geomorfologicznych, Maroko, 19.04-4.05.2006. SGP, WGiSR UW: 217-227.

Cooke R.U., Warren A., Goudie A.S., 1993. Desert Geomorphology. University College London Press, London.

Dainelli P., 2007. Geological Map of Boumalne 1:50 000. Ministere de L'Energie et des Mines, Direction du Developement Minier, S.E.L.C.A. - Florence, Italie.

de Jong C., Cappy S., Finckh M., Funk D., 2008. A transdisciplinary analysis of water problems in the mountainous karst areas of Morocco. Engineering Geology 99: 228-238.

de Jong C., Machauer R., Leavesely G., Cappy S., Poete P., Schulz O., 2005. Integrated hydrological modelling concepts for a peripheral 
mountainous semi-arid basin in southern Morocco. In: R. Escadafal, M.L. Paracchini (eds.), Geomatics for Land and Water Management: Achievements and Challenges in the Euromed Context. EC JRC Workshop proceedings: 219-227.

Frizon de Lamotte D., Saint Bezar B., Bracène R., Mercier E., 2000. The two main steps of the Atlas building and geodynamics of the western Mediterranean. Tectonics 19: 740-761. http://dx.doi.org/10.1029/2000TC900003

Graf W.L., 1988. Fluvial Processes in Dryland Riviers. Springer-Verlag, Berlin. http://dx.doi.org/10.1007/978-3-642-83048-8

Kotarba A., 1998. Landscape Ecology, Human Impact and Extreme Erosional Events in the Tatra Mountains. Poland. Ambio 27, 4: 354-357.

Kühle M., 1987. Physisch-geographische Merkmale des Hochgebirges: Zur Ökologie von Höhenstufen und Höhengrenzen. In: Hochgebirge. Ergebnisse neuer Forschungen. Forderfurter Beiträge zur Didaktik der Geographie 10, Forderfurt am Main: 15-40.

Laouina A., 2006. Zarys morfostrukturalny i geomorfologiczny Maroka. In: M. Dłużewski, I. Tsermegas (eds.), Geograficzne i geologiczne uwarunkowania rozwoju rzeźby Maroka. Materiały Warsztatów Geomorfologicznych, Maroko, 19.04-4.05.2006 r., SGP, WGiSR UW: 9-12.

Leopold L.B., Wolman M.G., Miller J.P., 1964. Fluvial Processes in Geomorphology. W.H. Freeman and Company, San Francisco.

Milhi A., 1997. Geological Map of Tinerhir 1:100 000. Ministere de L'Energie et des Mines, Direction de la Geologie, S.E.L.C.A. - Florence, Italie.

Powell D.M., Brazier R., Parsons A., Wainwright J., Nichols M., 2007. Sediment transfer and storage in dryland headwater streams. Geomorphology 88: 152-166. http://dx.doi.org/10.1016/j.geomorph.2006.11.001

Schulz O., Busche H., Benbouziane A., 2008. Decadal Precipitation Variances and Reservoir Inflow in the Semi-Arid Upper Drâa Basin (South-Eastern-Morocco). In: F. Zereini, H. Hötzl (eds.), Climatic changes and water resources in the Middle East and in North Africa. Springer, Berlin, Heidelberg: 165-178. http://dx.doi.org/10.1007/978-3-540-85047-2 13

Schulz O., de Jong C., 2004. Snowmelt and sublimation: field experiments and modeling in the High Atlas Mountains of Morocco. Hydrology and Earth System Sciences 8(6): 1076-1089. http://dx.doi.org/10.5194/hess-8-1076-2004

Stokes M., Mather A.E., Belfoul A., Farik F., 2008. Active and passive tectonic controls for transverse drainage and river gorge development in a collisional mountain belt (Dades Gorges, High Atlas Mountains, Morocco). Geomorphology 102: 2-20. http://dx.doi.org/10.1016/j.geomorph.2007.06.015

Strahler A.N., 1952. Dynamic basis of geomorphology. Bulletin of the Geological Society of America 63: 923-938. http://dx.doi.org/10.1130/0016-7606(1952)63[923:DBOG]2.0.CO;2

Thoot S., Nanson G.C., 2004. Forms and processes of two higly contrasting rivers in arid central Australia, and the implications for channel-pattern discrimination and prediction. Geological Society of America Bulletin 116: 802-816.

Thornes J.B., 1980. Structural instability and ephemeral channel behaviour. Zeitschrift für Geomorphologie, Supplement 36: 233-244. http://dx.doi.org/10.1130/B25308.1

Wysocki C., Sikorski P., 2009. Fitosocjologia stosowana w ochronie i kształtowaniu krajobrazu. Wyd. SGGW, Warszawa: 1-498. 